\title{
Mechanical Characterization of Lightweight Foamed Concrete
}

\author{
Marcin Kozłowski ${ }^{1}{ }^{1}$ and Marta Kadela ${ }^{2}{ }^{2}$ \\ ${ }^{1}$ Department of Structural Engineering, Faculty of Civil Engineering, Silesian University of Technology, \\ 5 Akademicka St., 44-100 Gliwice, Poland \\ ${ }^{2}$ Building Research Institute, 1 Filtrowa St., 00-611 Warszawa, Poland \\ Correspondence should be addressed to Marta Kadela; m.kadela@itb.pl
}

Received 3 October 2017; Accepted 20 December 2017; Published 18 March 2018

Academic Editor: Kai Wei

Copyright (c) 2018 Marcin Kozłowski and Marta Kadela. This is an open access article distributed under the Creative Commons Attribution License, which permits unrestricted use, distribution, and reproduction in any medium, provided the original work is properly cited.

\begin{abstract}
Foamed concrete shows excellent physical characteristics such as low self weight, relatively high strength and superb thermal and acoustic insulation properties. It allows for minimal consumption of aggregate, and by replacement of a part of cement by fly ash, it contributes to the waste utilization principles. For many years, the application of foamed concrete has been limited to backfill of retaining walls, insulation of foundations and roof tiles sound insulation. However, during the last few years, foamed concrete has become a promising material for structural purposes. A series of tests was carried out to examine mechanical properties of foamed concrete mixes without fly ash and with fly ash content. In addition, the influence of 25 cycles of freezing and thawing on the compressive strength was investigated. The apparent density of hardened foamed concrete is strongly correlated with the foam content in the mix. An increase of the density of foamed concrete results in a decrease of flexural strength. For the same densities, the compressive strength obtained for mixes containing fly ash is approximately $20 \%$ lower in comparison to the specimens without fly ash. Specimens subjected to 25 freeze-thaw cycles show approximately $15 \%$ lower compressive strengths compared to the untreated specimens.
\end{abstract}

\section{Introduction}

Foamed concrete is known as light-weight or cellular concrete. It is commonly defined as a cementitious material with a minimum of $20 \%$ (by volume) mechanically entrained foam in the mortar mix where air-pores are entrapped in the matrix by means of a suitable foaming agent [1]. It shows excellent physical characteristics such as low self weight, relatively high strength, and superb thermal and acoustic insulation properties. It allows for minimal consumption of aggregate, and by replacement of a part of cement by fly ash, it contributes to the waste utilization principles [2]. By a proper selection and dosage of components and the foaming agent, a wide range of densities $\left(300-1600 \mathrm{~kg} / \mathrm{m}^{3}\right)$ can be achieved for various structural purposes, insulation, or filling applications [2].

Foamed concrete has been known for almost a century and was patented in 1923 [3]. The first comprehensive study of foamed concrete was carried out in the 1950s and 1960s by
Valore $[3,4]$. Following this research, more detailed evaluation regarding the composition, properties, and applications of cellular concrete was reported by Rudnai [5], as well as by Short and Kinniburgh [6] in 1963. New mixtures were developed in the late 1970s and early 1980s, which led to the increased commercial use of foamed concrete in building constructions $[7,8]$.

For many years, the application of foamed concrete has been limited to backfill of retaining walls, insulation of foundations, and sound insulation [8]. However, in the last few years, foamed concrete has become a promising material also for structural purposes [7, 9], for example, stabilization of weak soils [10, 11], a base layer of sandwich solutions for foundation slabs [12], industrial floors [13], and highway as well as subway engineering applications [14, 15].

With the increasing environmental challenges, it is paramount that sustainable materials are researched for a wider range of applications to offer feasible alternatives alongside conventional materials. 
TABle 1: Mix proportions.

\begin{tabular}{|c|c|c|c|c|c|c|}
\hline Mix symbol & Foaming agent content $(1 / 100 \mathrm{~kg} \mathrm{C})$ & Cement (kg) & Fly ash (kg) & Water $(\mathrm{kg})$ & Foaming agent $(\mathrm{kg})$ & $w_{\text {eff }} / c(-)$ \\
\hline FC1 & 2.00 & 25.00 & 0.00 & 10.50 & 0.50 & 0.44 \\
\hline FC2 & 4.00 & 25.00 & 0.00 & 10.00 & 1.00 & 0.44 \\
\hline FC3 & 6.00 & 25.00 & 0.00 & 9.50 & 1.50 & 0.44 \\
\hline FC4 & 8.00 & 25.00 & 0.00 & 9.00 & 2.00 & 0.44 \\
\hline FC5 & 10.00 & 25.00 & 0.00 & 8.50 & 2.50 & 0.44 \\
\hline FCA1 & 2.00 & 25.00 & 1.25 & 10.50 & 0.50 & 0.44 \\
\hline FCA2 & 4.00 & 25.00 & 1.25 & 10.00 & 1.00 & 0.44 \\
\hline FCA3 & 6.00 & 25.00 & 1.25 & 9.50 & 1.50 & 0.44 \\
\hline FCA4 & 8.00 & 25.00 & 1.25 & 9.00 & 2.00 & 0.44 \\
\hline FCA5 & 10.00 & 25.00 & 1.25 & 8.50 & 2.50 & 0.44 \\
\hline
\end{tabular}

Table 2: Cement chemical composition (\%).

\begin{tabular}{ccccccccc}
\hline $\mathrm{SiO}_{2}$ & $\mathrm{Al}_{2} \mathrm{O}_{3}$ & $\mathrm{Fe}_{2} \mathrm{O}_{3}$ & $\mathrm{CaO}$ & $\mathrm{MgO}$ & $\mathrm{SO}_{3}$ & $\mathrm{Na}_{2} \mathrm{O}$ & $\mathrm{K}_{2} \mathrm{O}$ & $\mathrm{Cl}$ \\
\hline 19.5 & 4.9 & 2.9 & 63.3 & 1.3 & 2.8 & 0.1 & 0.9 & 0.05 \\
\hline
\end{tabular}

TABle 3: Physical properties of cement.

\begin{tabular}{lccc}
\hline $\begin{array}{l}\text { Specific surface } \\
\text { area }\left(\mathrm{m}^{2} / \mathrm{kg}\right)\end{array}$ & $\begin{array}{c}\text { Specific gravity } \\
\left(\mathrm{g} / \mathrm{cm}^{3}\right)\end{array}$ & \multicolumn{2}{c}{$\begin{array}{c}\text { Compressive } \\
\text { strength }(\mathrm{MPa}) \\
\text { After days }\end{array}$} \\
\hline 3840 & 3.06 & 2 & 28 \\
\hline
\end{tabular}

Foamed concrete, being an alternative to ordinary concrete, fulfills the criteria of the principles of sustainability in building constructions [16-18]. The general principles, based on the concept of sustainable development as it applies to the life cycle of buildings and other construction works, are identified in ISO 15392:2008. First, foamed concrete consumes relatively low amount of raw material in relation to the amount of hardened state. Second, during its production, recycled materials such as fly ash can be used. In this way, foamed concrete contributes to the disposal of waste products of thermal power plants. Third, foamed concrete can be recycled and used as replacement of sand in insulation materials. Moreover, the manufacturing of foamed concrete is nontoxic, and the product does not emit toxic gases when it is exposed to fire. At last, it is cost-effective not only during the construction stage but also throughout lifetime operation and maintenance of the structure.

Besides contribution to the disposal of the waste products of thermal power plants, the addition of fly ash improves the workability of the fresh foamed concrete mix and has positive effect on drying shrinkage $[2,19]$. On one hand, the only drawback of this mineral additive is lower early strength of mortar in comparison to the mix without fly ash [20]. On the other, it has been proven that the long-term strength is improved $[19,21]$.

Despite its favourable and promising strength and physical properties, foamed concrete is still utilized in limited scale, particularly for structural applications. This is mainly due to the insufficient knowledge regarding its mechanical properties and small number of research on its fracture behaviour [22-28].
TABle 4: Fly ash chemical composition (\%).

\begin{tabular}{cccccccc}
\hline $\mathrm{SiO}_{2}$ & $\mathrm{Al}_{2} \mathrm{O}_{3}$ & $\mathrm{Fe}_{2} \mathrm{O}_{3}$ & $\mathrm{CaO}$ & $\mathrm{MgO}$ & $\mathrm{SO}_{3}$ & $\mathrm{Na}_{2} \mathrm{O}$ & $\mathrm{K}_{2} \mathrm{O}$ \\
\hline 76.5 & 1.42 & 5.80 & 3.61 & 1.63 & 0.263 & 0.038 & 0.096 \\
\hline
\end{tabular}

The main objective of this work is to investigate the mechanical characteristics of foamed concrete with varying density $\left(400-1400 \mathrm{~kg} / \mathrm{m}^{3}\right)$. A series of tests was performed to examine compressive strength, elastic modulus, flexural strength, and material degradation characteristics after freeze-thaw cycles.

\section{Experimental Program}

2.1. Specimens Preparation and Concrete Mix Composition. The materials used in this study were Portland cement, fly ash, water, and foaming agent. The compositions of the mix are presented in Table 1 . The industrial Portland cement was CEM I 42.5 R [29], according to PN-EN 197-1: 2011. Its chemical composition and physical properties, measured as per PN-EN 196-6:2011 and PN-EN 196-6:2011-4, are given in Tables 2 and 3. Tap water was used in all experiments. Compressive strength of cement was determined according to PN-EN 196-1:2016-07 (Table 3).

To improve the workability and reduce shrinkage, fly ash was used in some mixes. The ash used met the requirements of PN-EN 450-1:2012. Its chemical composition is given in Table 4.

A commercial foaming agent was used to produce foam. The liquid agent was pressurized with air at approximately 5 bars in order to make the stable foam with a density of approximately $50 \mathrm{~kg} / \mathrm{m}^{3}$. Cement pastes with $2 \div 10$ litres of liquid foaming agent for $100 \mathrm{~kg}$ of cement were prepared.

Two different types of concrete mixes (one without fly ash and the other with fly ash) were used. In total, 10 mixes were produced, five specimens for one concrete mix (Table 1). A constant $w_{\text {eff }} / c=0.44$ ratio was used for all mixes $\left(w_{\text {eff }}\right.$ includes water and liquid foaming agent; $c$ is the cement content). It was based on the results of Jones and McCarthy [7] and Xianjun et al. [30]. The target densities of hardened foamed concrete to be produced in this study were from 400 to $1400 \mathrm{~kg} / \mathrm{m}^{3}$.

The entire manufacturing process of foamed concrete must carefully consider the densities of the mix, the foaming production rate, and other factors in order to prepare high- 


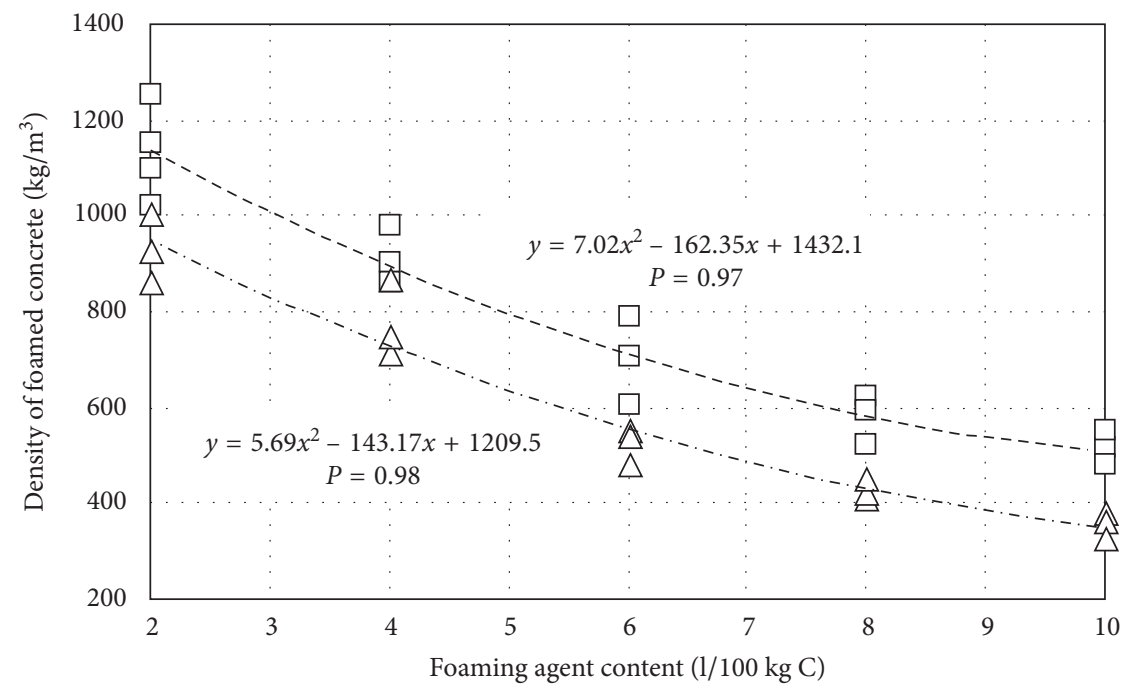

$\square \mathrm{FC}$

$\triangle$ FCA

FIgURE 1: Apparent density of foamed concrete specimens FC and FCA as a function of foaming agent content.

quality foamed concrete. The key factors to produce stable foamed concrete were pressurizing of foaming agent at stable pressure and constant rotational speed of mixing the components.

All specimens, after casting in steel moulds, were covered and stored in a curing room at $20 \pm 1^{\circ} \mathrm{C}$ and $95 \%$ humidity for 24 hours. Subsequently, the samples were removed from the moulds and stored in ambient conditions (at $20 \pm 1^{\circ} \mathrm{C}$ and $60 \pm 10 \%$ humidity) for 28 or 42 days before testing.

2.2. Tests. Foamed concrete is a relatively new material, and currently there are no standardized test methods to measure its physical and mechanical properties. Therefore, procedures for preparation of specimens and testing methods, usually used for ordinary concrete, were adapted in this research. The compressive strength, modulus of elasticity, and flexural strength were determined according to the recommendations: PN-EN 12390-3:2011 + AC:2012, Instruction of Research Building Institute No. 194/98, PN-EN 12390-13:2014, and PNEN 12390-5:2011, respectively. The density was measured as per PN-EN 12390-7:2011.

Compressive strength was measured with $150 \times 150 \times 150 \mathrm{~mm}$ standard cubes as stated in PN-EN 12390-3:2011 + AC:2012. The loading rate was assumed according to PN-EN 772-1: $2015+$ A1:2015 as for cellular concrete masonry units.

Elasticity modulus was determined according to the Instruction of Research Building Institute No. 194/98 and PN-EN 12390-13:2014-02 with cylindrical specimens with the dimensions of $150 \times 300 \mathrm{~mm}$. The loading rate was $0.1 \pm$ $0.05 \mathrm{MPa} / \mathrm{s}$, according to PN-EN 679:2008 as for cellular concrete masonry units. Two electrical resistance strain gauges with $100 \mathrm{~mm}$ measurement length were bonded on two opposite sides of the specimens at mid-height. The stress-strain characteristic was recorded for the evaluation of modulus of elasticity.

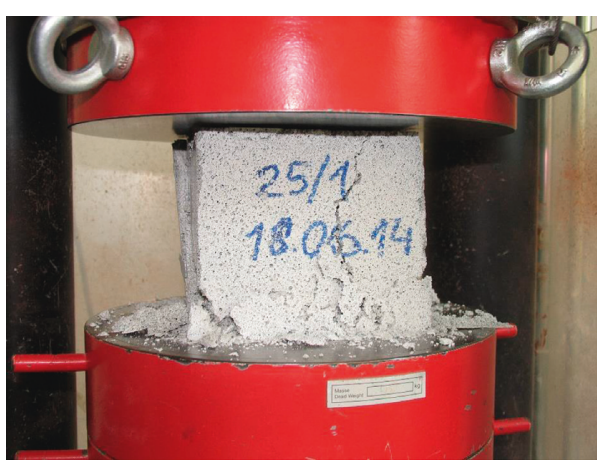

FIGURE 2: Typical failure pattern observed during compression tests with cube specimens.

Flexural strength was tested in three-point bending setup with beams $100 \times 100 \times 500 \mathrm{~mm}$, according to PN-EN 12390-5:2011. The nominal distance between the supports was $300 \mathrm{~mm}$. The rollers allowed for free horizontal movement. The specimens were loaded at constant displacement rate of $0.1 \mathrm{~mm} / \mathrm{min}$ as an optimum value determined experimentally.

Degradation characteristics under freeze-thaw cycles were evaluated with $150 \times 150 \times 150 \mathrm{~mm}$ standard cubes. The compressive strength was determined with the procedure as described before. The test campaign consisted of 25 cycles of freezing and thawing. Each cycle included cooling of the specimens to the temperature of $-18^{\circ} \mathrm{C}$ within $2 \mathrm{~h}$. The samples were then kept frozen for $8 \mathrm{~h}$ at $-18 \pm 2^{\circ} \mathrm{C}$ and thawed in water at the temperature of $+19^{\circ} \mathrm{C} \pm 1^{\circ} \mathrm{C}$ for $4 \mathrm{~h}$. Reference specimens were kept immerse in water as references.

\section{Results and Discussion}

3.1. Apparent Density. The dosage of foaming agent highly influences the density of mix and hardened foamed concrete. 


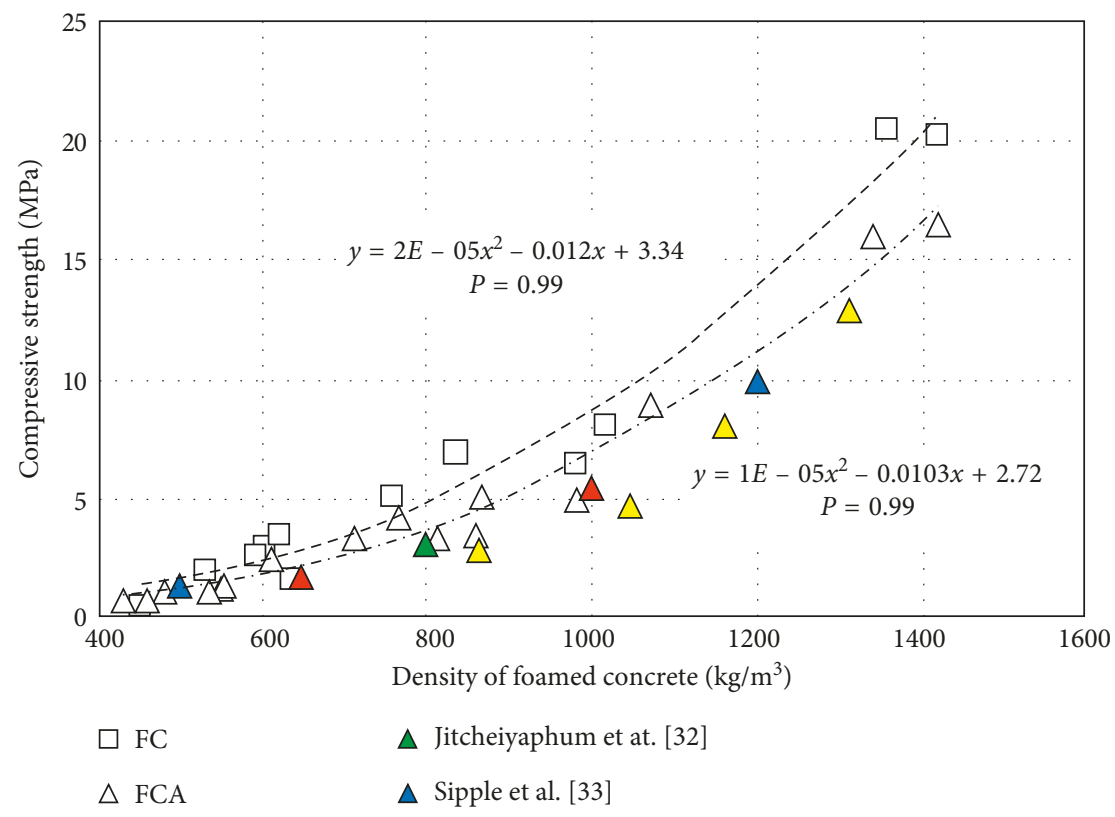

$\Delta$ Mydin and Wang [31] $\triangle$ Marunmale and Attar [34]

FIGURE 3: Compressive strengths of foamed concrete FC and FCA as a function of density of foamed concrete.

Figure 1 shows the relationship between the dosage of foaming agent and the apparent density of hardened foamed concrete for the specimens without fly ash (FC) and the other with fly ash (FCA). The apparent density of hardened foamed concrete is strongly correlated with the foam content and the composition of cement paste and air voids in fresh mix. The increase of foam content is accompanied by the increase of volume of fresh concrete, which results in a decrease of density of hardened foamed concrete. It can be observed that there are exponential relationships for FC and FCA specimens. Moreover, results obtained in FC show density level of approximately $20 \%$ higher than FCA. This can be explained by the fact that the process of hardening is slowed down in the specimens containing fly ash. The physical reaction between fly ash and air-pores results in larger number of air-pores entrapped in the mix. It was also found that the mixes with the foaming agent content above 10 litres per $100 \mathrm{~kg}$ of cement resulted in unstable mix. The results were approximated with polynomial functions as shown in Figure 1.

3.2. Compressive Strength. Cube foamed concrete specimens tested in compression present the mechanism of failure similar to ordinary concrete. A typical conical postbreakage failure pattern was observed for all specimens (Figure 2).

The compressive strengths of foamed concrete without ash (FC) and foamed concrete with addition of fly ash (FCA) as a function of apparent density are presented in Figure 3. It can be noticed that there are exponential relationships for both FC and FCA; however, there seems to be a difference between the strengths obtained from FC and FCA samples. The specimens without ash seem to show higher strengths than the mixtures containing ash. This is due to the fact that the process of hardening is slowed down due to the presence

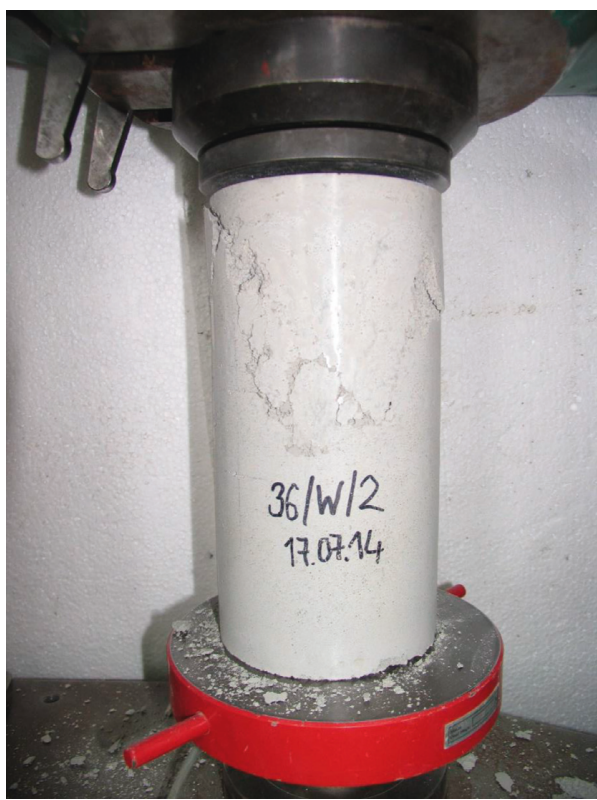

FIGURE 4: Typical failure pattern observed during compression tests with cylindrical specimens.

of fly ash [20]. In addition, this difference increases along with the density. The values of compressive strengths obtained correspond to the results of the works of others [31-34]. The results were approximated with polynomial functions as shown in Figure 3.

3.3. Modulus of Elasticity. Cylindrical foamed concrete specimens tested in compression present the mechanism of failure similar to ordinary concrete. A typical conical postbreakage failure pattern was observed for all specimens 


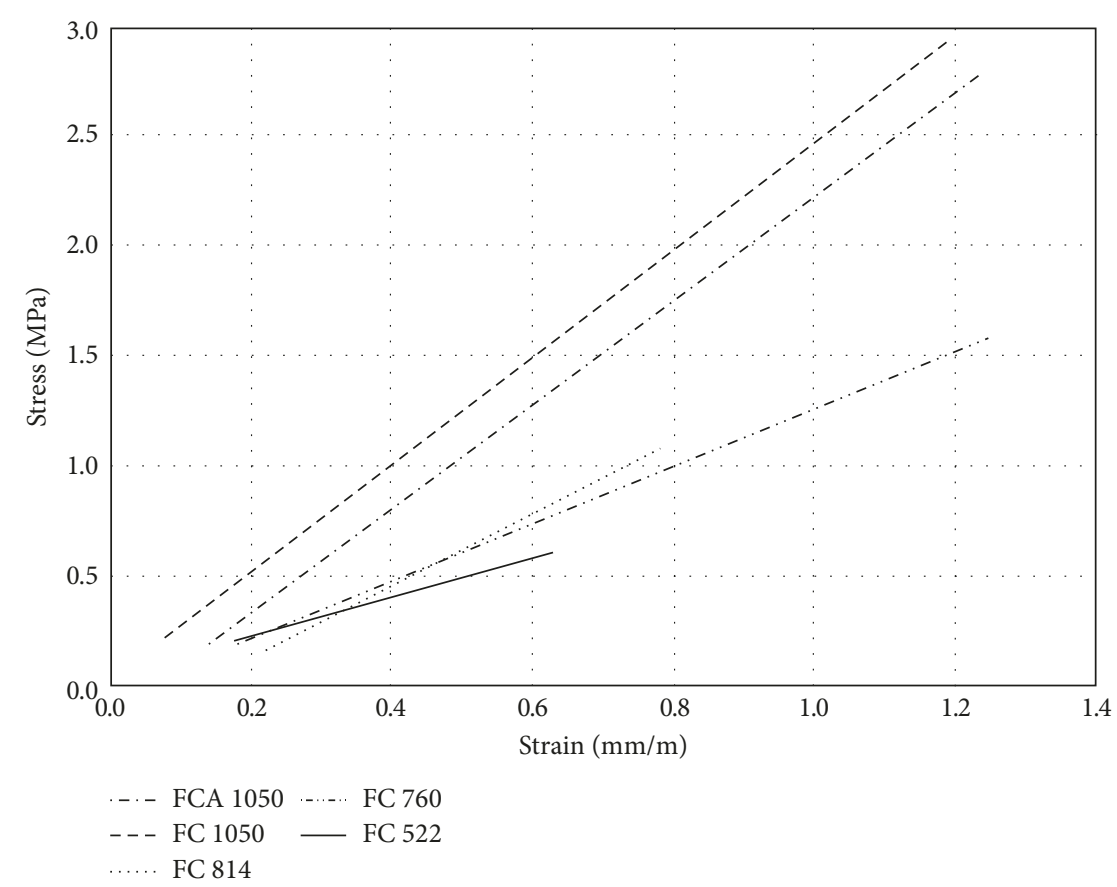

FIGURE 5: Stress-strain relationships of cylindrical specimens FC and FCA.

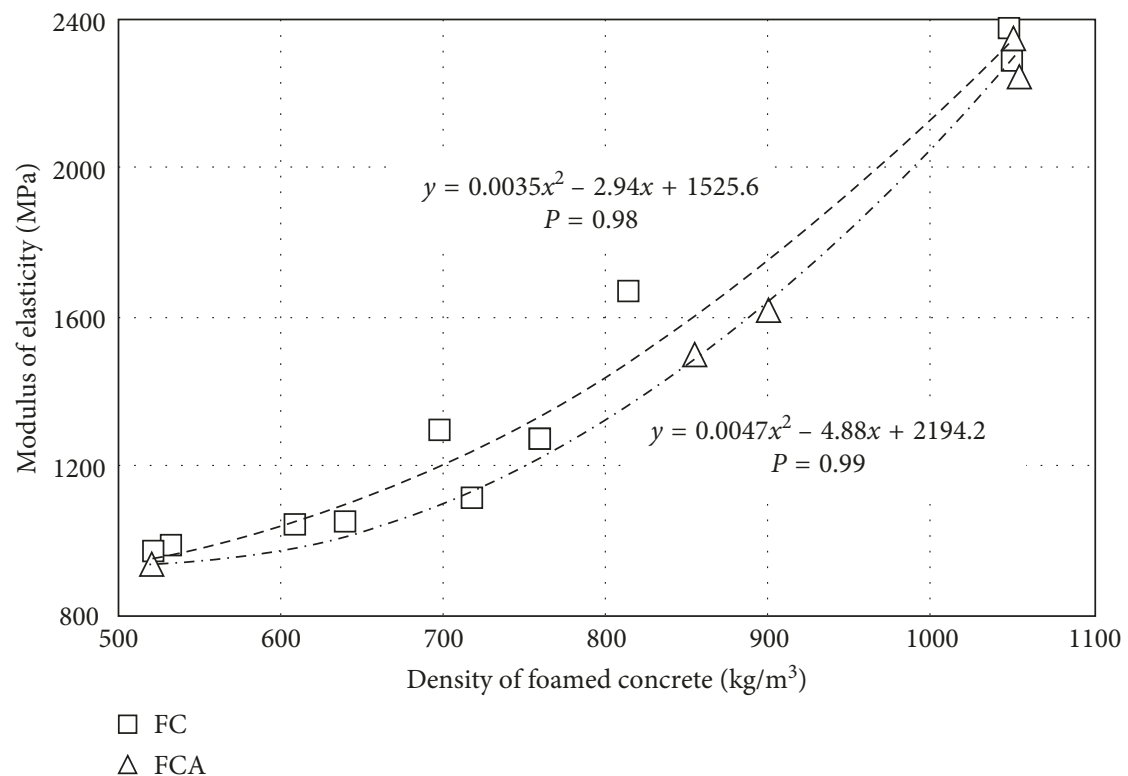

FIGURE 6: Modulus of elasticity of foamed concrete FC and FCA as a function of density of foamed concrete.

(Figure 4). Stress-strain relationships of cylindrical specimens are presented in Figure 5. The plots show the relations in the range of $0.2 \mathrm{MPa}$ until failure, according to PN-EN 12390-13: 2014-02.

Figure 6 shows the relationships between the modulus of elasticity of foamed concrete and its density. It can be observed that there are exponential relationships for FC and FCA. The specimens without fly ash seem to have higher modulus of elasticity than the mixtures containing fly ash
[35]. The values of modulus of elasticity obtained correspond to the results of the works of Aldridge [8].

3.4. Flexural Strength. Figure 7 presents the relationship between the density of foamed concrete and the flexural strength. The tests were carried out on specimens without fly ash. Figure 7 includes also the results of experiments carried out by authors and reported in [23-28]. The decrease of 


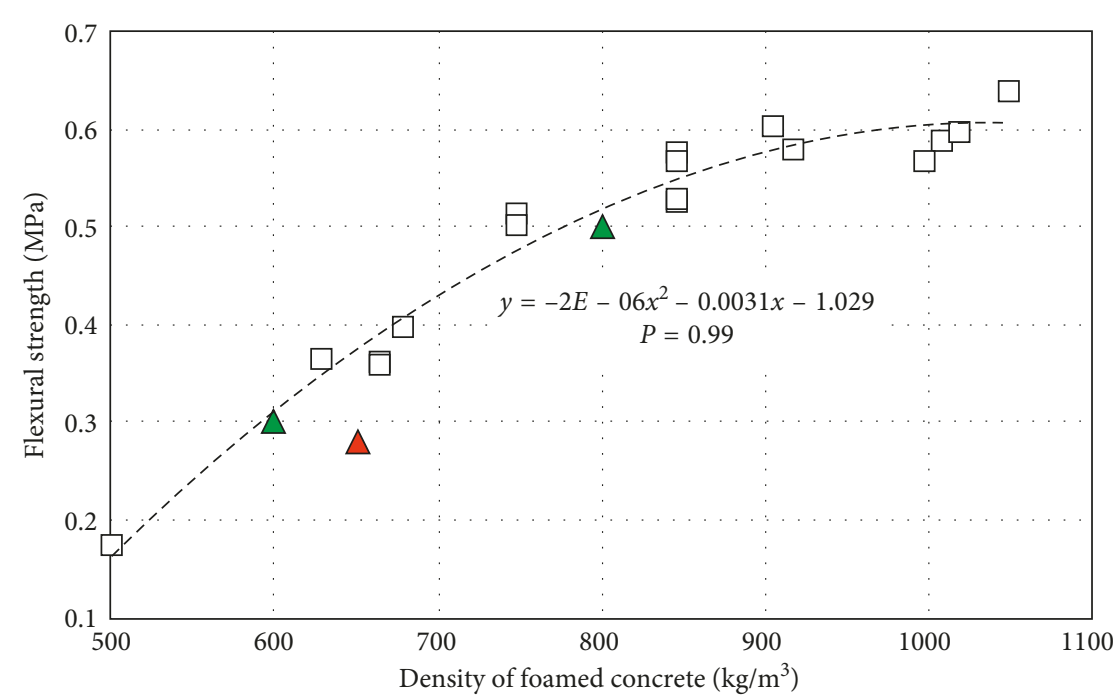

$\square$ FC

$\triangle$ Mydin and Wang [31]

$\Delta$ Soleimanzadeh and Mydin [36]

FIGURE 7: Flexural strength as a function of density of foamed concrete.

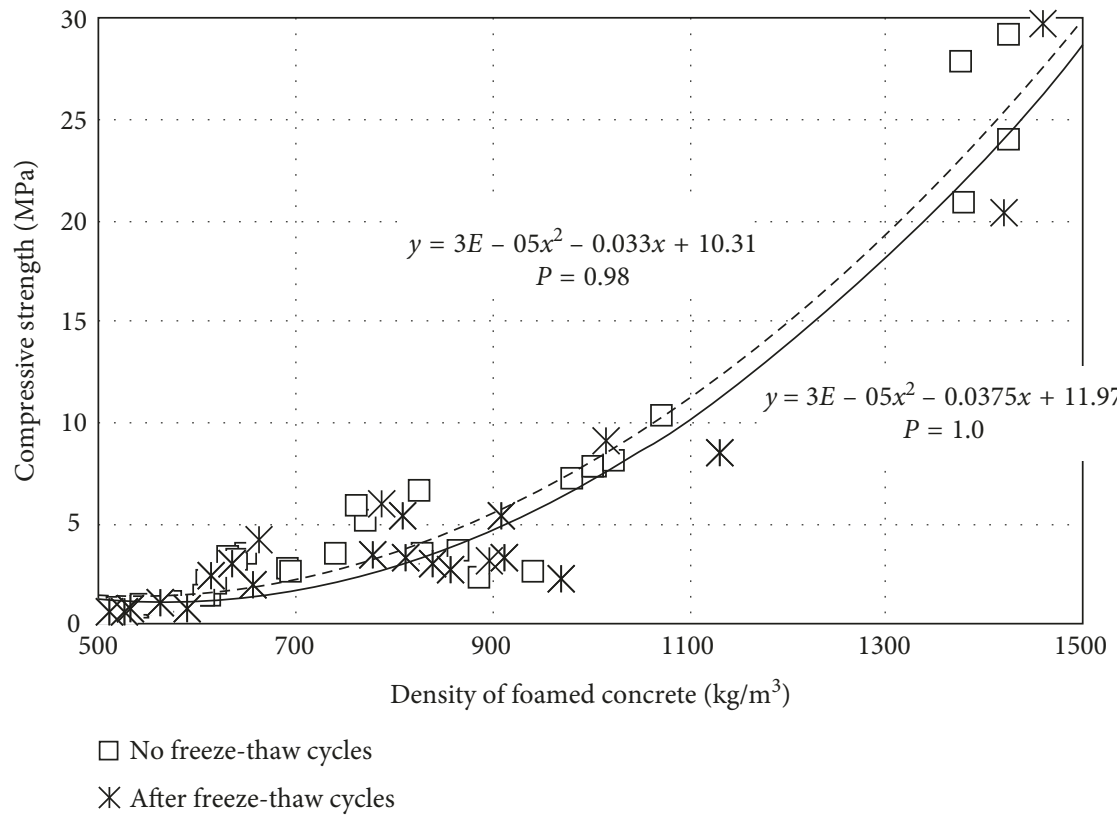

Figure 8: Compressive strength of foamed concrete after 25 freeze-thaw cycles as a function of density.

flexural tensile strength with the decrease of the density of the foamed concrete can be noted. The values of flexural strengths correspond to the results of works of Mydin and Wang [31] and Soleimanzadeh and Mydin [36].

3.5. Degradation Characteristics under Freeze-Thaw Cycles. Figure 8 shows the results of compressive strength of foamed concrete after 25 freeze-thaw cycles as a function of density. As a reference, results from untreated samples are shown in Figure 8. The freeze-thaw treatment of the specimens has only minor influence on the compressive strength of foamed concrete. The strengths obtained for the specimens subjected to freeze-thaw cycles showed approximately $15 \%$ lower values. The results were approximated with polynomial functions as shown in Figure 8 .

\section{Conclusions}

Foamed concrete can achieve much lower densities (400 to $1400 \mathrm{~kg} / \mathrm{m}^{3}$ ) in comparison to conventional concrete. A 
series of tests was carried out to examine the mechanical parameters of foamed concrete: compressive strength, flexural strength, and modulus of elasticity. Furthermore, the influence of 25 cycles of freezing and thawing on the compressive strength was examined.

The main conclusions that can be drawn from this study are the following:

(i) The dosage of foaming agent influences the density of mix and hardened foamed concrete. The density of foamed concrete is strongly correlated with the foam content in the mix.

(ii) The compressive strength, modulus of elasticity, and flexural strength decreased with the decrease of the density of the foamed concrete; the polynomial functions were suggested to describe these relationships.

(iii) The compressive strength and modulus of elasticity of foamed concrete were slightly decreased by the addition of $5 \%$ of fly ash.

(iv) The compressive strength of foamed concrete subjected to freeze-thaw tests shows the values only approximately $15 \%$ lower comparing to untreated specimens.

\section{Conflicts of Interest}

The authors declare that they have no conflicts of interest.

\section{Acknowledgments}

This work was supported by the ongoing research project "Stabilization of weak soil by application of layer of foamed concrete used in contact with subsoil" (LIDER/022/537/ L-4/NCBR/2013) financed by the National Centre for Research and Development within the LIDER Programme. The authors gratefully acknowledge the skills and commitment of laboratory technician Alfred Kukiełka, without whom the present study could not have been successfully completed.

\section{References}

[1] S. Van Deijk, Foamed Concrete: In A Dutch View, British Cement Association, Blackwater, UK, 1992.

[2] R. Ramamurthy, E. K. Kunhanandan Nambiar, and G. Indu Siva Ranjani, "A classification of studies on properties of foam concrete," Cement and Concrete Composites, vol. 31, no. 6, pp. 388-396, 2009.

[3] R. C. Valore, "Cellular concrete part 1 composition and methods of production," ACI Journal Proceedings, vol. 50, no. 5, pp. 773-796, 1954.

[4] R. C. Valore, "Cellular concrete part 2 physical properties," ACI Journal Proceedings, vol. 50, no. 6, pp. 817-836, 1954.

[5] G. Rudnai, Lightweight Concretes, Akademikiado, Budapest, Hungary, 1963.

[6] A. Short and W. Kinniburgh, Lightweight Concrete, Asia Publishing House, Delhi, India, 1963.

[7] M. R. Jones and A. McCarthy, "Preliminary views on the potential of foamed concrete as a structural material," Magazine of Concrete Research, vol. 57, no. 1, pp. 21-31, 2005.

[8] D. Aldridge, "Introduction to foamed concrete: what, why, how?," in Use of Foamed Concrete in Construction:
Proceedings of the International Conference, Dundee, Scotland, UK, K. Ravindra, D. Moray, and M. Aikaterini, Eds., vol. 5, pp. 1-14, July 2005.

[9] R. K. Dhir, M. D. Newlands, and A. McCarthy, Use of Foamed Concrete in Construction, Thomas Telford, London, UK, 2005.

[10] M. Drusa, L. Fedorowicz, M. Kadela, and W. Scherfel, “Application of geotechnical models in the description of composite foamed concrete used in contact layer with the subsoil," in Proceedings of the 10th Slovak Geotechnical Conference on Geotechnical Problems of Engineering Constructions, Bratislava, Slovakia, May 2011.

[11] L. Fedorowicz, M. Kadela, and Ł. Bednarski, "Modeling of the foamed concrete behavior for the layered structures cooperating with subsoil," in Technical Notes of Katowice School of Technology, vol. 6, pp. 73-81, Katowice School of Technology, Katowice, Poland, 2014.

[12] J. Hulimka, A. Knoppik-Wróbel, R. Krzywoń, and R. Rudišin, "Possibilities of the structural use of foamed concrete on the example of slab foundation," in Proceedings of the 9th Central European Congress on Concrete Engineering, pp. 67-74, Wroclaw, Poland, June 2013.

[13] M. Kadela and M. Kozłowski, "Foamed concrete layer as substructure of industrial concrete floor," Procedia Engineering, vol. 161, pp. 468-476, 2016.

[14] M. R. Jones and A. McCarthy, "Behaviour and assessment of foamed concrete for construction applications," in Use of Foamed Concrete in Construction: Proceedings of the International Conference, Dundee, Scotland, UK, K. Ravindra, D. Moray, and M. Aikaterini, Eds., vol. 5, pp. 61-88, July 2005.

[15] W. Tian, L. Li, X. Zhao, M. Zhou, and N. Wamg, "Application of foamed concrete in road engineering," in Proceedings of International Conference on Transportation Engineering, ASCE, pp. 2114-2120, Chengdu, China, July 2009.

[16] K. K. B. Siram and K. Arjun Raj, "Concrete + Green = Foam Concrete," International Journal of Civil Engineering and Technology, vol. 4, pp. 179-184, 2013.

[17] A. S. Moon and V. Varghese, "Sustainable construction with foam concrete as a green building material," International Journal of Modern Trends in Engineering and Research, vol. 2, pp. 13-16, 2014.

[18] A. S. Moon, V. Varghese, and S. S. Waghmare, "Foam concrete as a green building material," International Journal of Research in Engineering and Technology, vol. 2, pp. 25-32, 2015.

[19] P. Chindaprasirt, S. Homwuttiwong, and V. Sirivivatnanon, "Influence of fly ash fineness on strength, drying shrinkage and sulfate resistance of blended cement mortar," Cement and Concrete Research, vol. 34, no. 7, pp. 1087-1092, 2004.

[20] P. Chindaprasirt and S. Rukzon, "Strength, porosity and corrosion resistance of ternary blend Portland cement, rice husk ash and fly ash mortar," Construction and Building Materials, vol. 22, no. 8, pp. 1601-1606, 2008.

[21] E. P. Kearsley and P. J. Wainwright, "The effect of high fly ash content on the compressive strength of foamed concrete," Cement and Concrete Research, vol. 31, no. 1, pp. 106-112, 2001.

[22] N. A. Rahman, Z. M. Jaini, and N. N. Zahir, "Fracture energy of foamed concrete by means of the three-point bending tests on notched beam specimens," Journal of Engineering and Applied Sciences, vol. 10, pp. 6562-6570, 2015.

[23] M. Kozłowski, M. Kadela, and A. Kukiełka, "Fracture energy of foamed concrete based on three-point bending test on notched beams in Proceedings of the 7th Scientific-Technical Conference on Material Problems in Civil Engineering MATBUD’2015," Procedia Engineering, vol. 108, pp. 349-354, 2015. 
[24] M. Kozłowski, M. Kadela, and M. Gwóźdź-Lasoń, "Numerical fracture analysis of foamed concrete beam using XFEM method," Applied Mechanics and Materials, vol. 837, pp. 183-186, 2016.

[25] M. Kadela, A. Cińcio, and M. Kozłowski, "Degradation analysis of notched foam concrete beam," Applied Mechanics and Materials, vol. 797, pp. 96-100, 2016.

[26] A. Cińcio, M. Kozłowski, M. Kadela, and D. Dudek, "Numerical degradation analysis of foamed concrete beam," in Proceedings of the 13th International Conference on New Trends in Statics and Dynamics of Buildings, Slovak university of Technology, Bratislava, Slovakia, October 2015.

[27] M. Kozłowski, M. Kadela, and M. Gwóźdź-Lasoń, "XFEM fracture analysis of notched foamed concrete beams," in Proceedings of the 13th International Conference on New Trends in Statics and Dynamics of Buildings, Slovak university of Technology, Bratislava, Slovakia, October 2015.

[28] M. Kozłowski and M. Kadela, "Experimental and numerical investigation of fracture behavior of foamed concrete based on three-point bending test of beams with initial notch," in Proceedings of the International Conference on Mechanical, Civil and Material Engineering, Barcelona, Spain, August 2015.

[29] Technical Data Sheet CEM I 42.5 R, http://www.gorazdze.pl.

[30] T. Xianjun, C. Weizhong, H. Yingge, and W. Xu, "Experimental Study of Ultralight $(<300 \mathrm{~kg} / \mathrm{m} 3)$ Foamed Concrete," Advances in Materials Science and Engineering, vol. 2014, Article ID 514759, 7 pages, 2014.

[31] M. A. O. Mydin and Y. C. Wang, "Mechanical properties of foamed concrete exposed to high temperatures," Construction and Building Materials, vol. 26, no. 1, pp. 638-654, 2012.

[32] K. Jitchaiyaphum, T. Sinsiri, and P. Chindaprasirt, "Cellular lightweight concrete containing pozzolan materials," Procedia Engineering, vol. 14, pp. 1157-1164, 2011.

[33] M. A. Sipple, "High strength self-compacting foam concrete. initial thesis report," ACME, UNSW@ADFA, https://www. researchgate.net/publication/265483433_Structural_Strength_ Self-Compacting_Foam_Concrete, 2009.

[34] A. K. Marunmale and A. C. Attar, "Designing, developing and testing of cellular lightweight concrete brick (CLC) wall built in rat-trap bond," Current Trends in Technology and Sciences, vol. 3, pp. 331-336, 2014.

[35] M. Kadela and A. Kukiełka, "Influence of foaming agent content in fresh concrete on elasticity modulus of hard foam concrete," in Brittle Matrix Composites 11-Proceedings of the 11th International Symposium on Brittle Matrix Composites BMC 2015, Institute of Fundamental Technological Research PAS, pp. 489-496, Warszawa, Poland, September 2015, ISBN: 978-838968796-8.

[36] S. Soleimanzadeh and M. A. O. Mydin, "Influence of high temperatures on flexural strength of foamed concrete containing fly ash and polypropylene fiber," International Journal of Engineering, vol. 26, no. 2, pp. 117-126, 2013. 


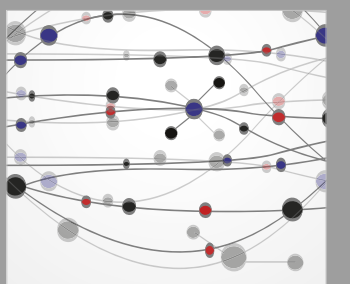

The Scientific World Journal
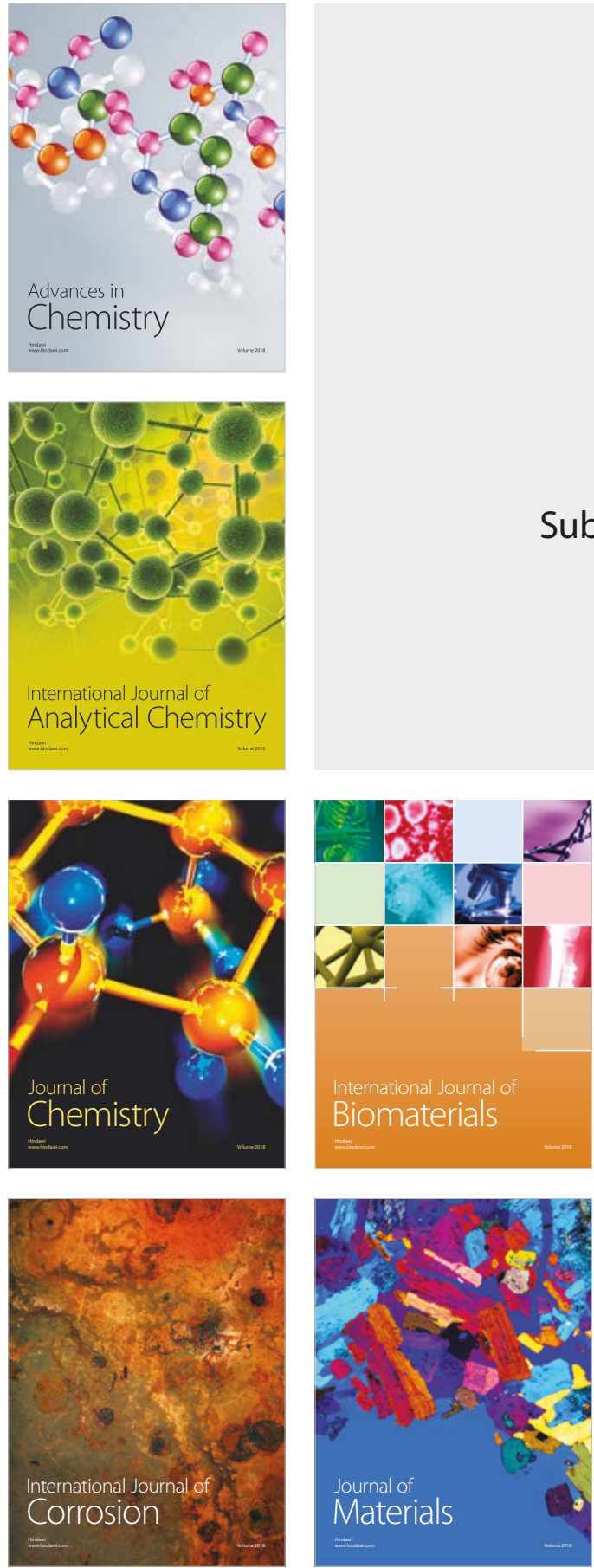

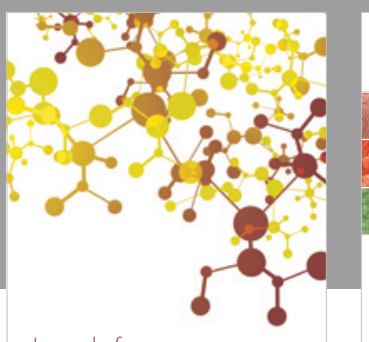

Journal of

Applied Chemistry
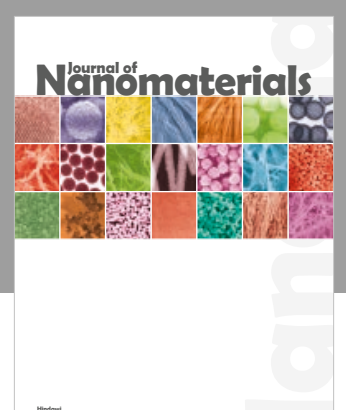

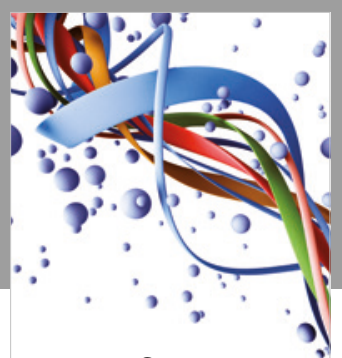

Scientifica

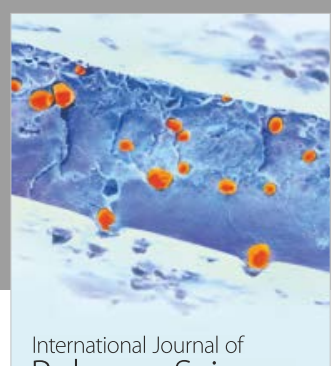

Polymer Science

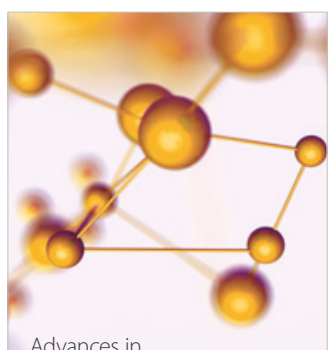

Physical Chemistry
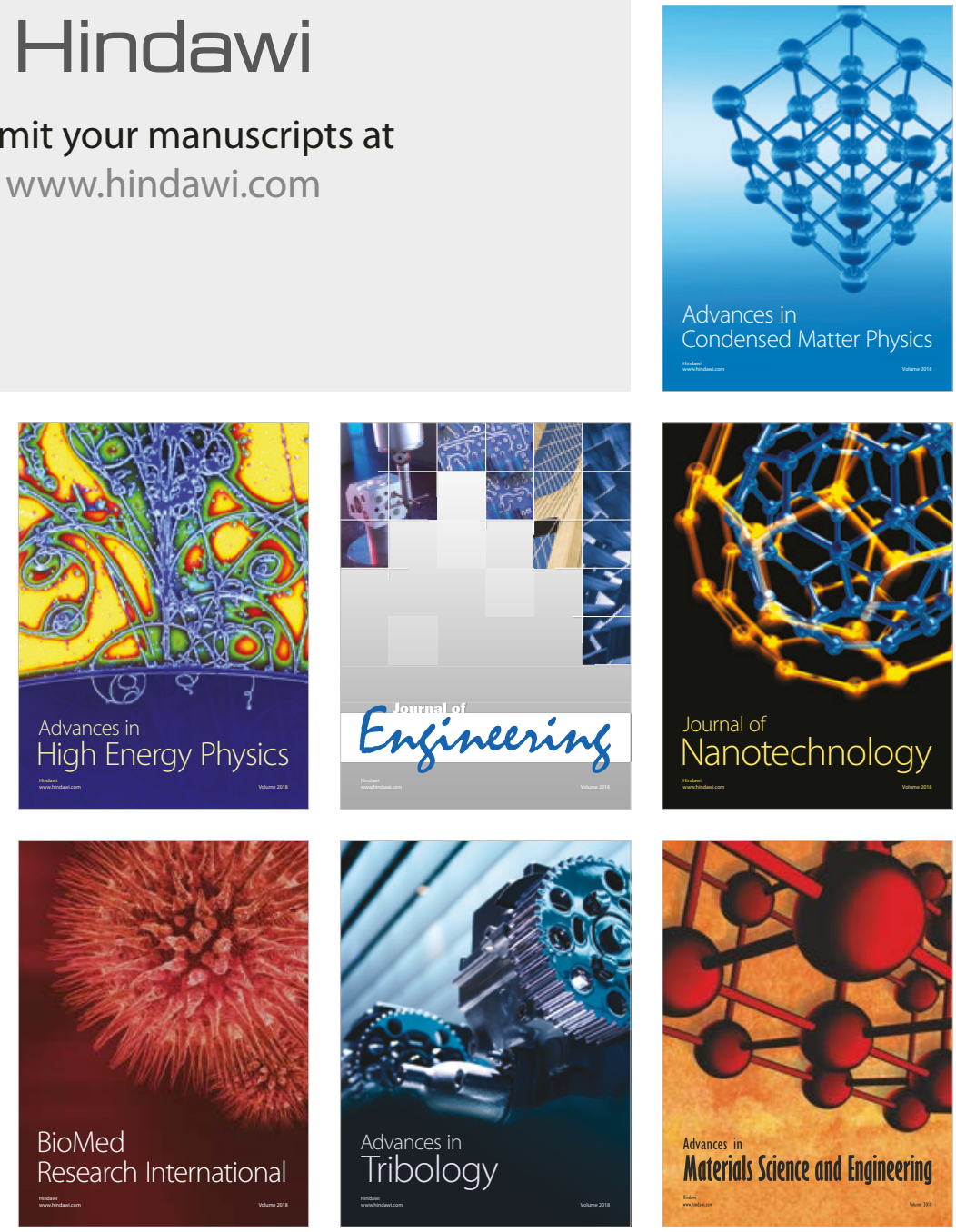